\title{
Civil Protective Orders in Integrated Domestic Violence Court: An Empirical Study
}

\section{Citation}

Civil Protective Orders in Integrated Domestic Violence Court: An Empirical Study (2010).

\section{Permanent link}

http://nrs.harvard.edu/urn-3:HUL.InstRepos:4772900

\section{Terms of Use}

This article was downloaded from Harvard University's DASH repository, and is made available under the terms and conditions applicable to Other Posted Material, as set forth at http:// nrs.harvard.edu/urn-3:HUL.InstRepos:dash.current.terms-of-use\#LAA

\section{Share Your Story}

The Harvard community has made this article openly available. Please share how this access benefits you. Submit a story. 


\title{
Civil Protective Orders in Integrated Domestic Violence Court: An Empirical Study
}

\author{
by Erika Rickard*
}

\section{Introduction}

The introduction of the Violence Against Women Act ("VAWA") in $1994^{1}$ led to higher arrest levels and availability of protective orders, ${ }^{2}$ causing a significant increase in the number of domestic violence cases coming through the courts. In the decades that followed, courts sought to accommodate this caseload through various alternatives to the traditional adversarial procedure. ${ }^{3}$ Across the country, a plethora of domestic violence focus groups, pilot projects, and institutionalized courts have been implemented. ${ }^{4}$

One approach was the development of specialized courts tailored to situations of domestic violence. Domestic violence courts are considered "problem-solving courts," addressing both the legal and non-legal concerns of the parties involved. ${ }^{5}$ These courts hear only domestic violence

\footnotetext{
* Law Clerk, Massachsetts Appeals Court, 2010-2011; Massachusetts Assistant Attorney General as of September 2011; J.D., Havard Law School, 2010. The author would like to thank Professors Lynn LoPucki of UCLA School of Law and Elizabeth Warren of Harvard Law School for their guidance, and Parina Patel, PhD candidate at Rutgers University, for her invaluable guidance in statistical analysis.

${ }^{1}$ Anat Maytal, Specialized Domestic Violence Courts: Are They Worth the Trouble in Massachusetts?, 18 B.U. PUB. InT. L.J. 197, 206 (2008) (brief summary of VAWA). See also Brenda K. Uekert, Violence Against Women Act Formula Grants for State Courts, Nat'l Ctr. for St. Cts. (2003).

2 Susan Keilitz et al., Specialization of Domestic Violence Case Management in the Courts: A National Survey, Nat'l Ctr. for St. Cts. 1, 1 (2000), available at http://www.ncjrs.gov/pdffiles1/nij/grants/186192.pdf.

3 From 1989 to 1999 , domestic violence filings in state courts increased by $178 \%$. Keilitz, supra note 2, at 3 (citing statistics from Brian Ostrom \& Neal Kauder, Examining the Work of State Courts, 1998, Nat'l Ctr. for St. Cts. (1999)). Domestic violence filings include civil and criminal filings.

${ }^{4}$ Robyn Mazur \& Liberty Aldrich, What Makes a Domestic Violence Court Work? Lessons from New York, 42 JUDGES' J. 5, 5-6 (2003) (describing the first court to specialize in issues related to domestic violence in Dade County, Florida in 1992); Pamela M. Casey \& David B. Rottman, Problem-Solving Courts: Models and Trends, 26 JusT. Sys. J. 35, 39 (2005) (VAWA funding in 1994 led to the rapid proliferation of specialized courts); see also Maytal, supra note 1, at 209.

$5^{5}$ Casey, supra note 4 , at 35.
} 
cases, based on criteria unique to the individual court. ${ }^{6}$ In a national survey of domestic violence courts by the National Center for State Courts, judges and court administrators expressed three primary reasons for establishing such courts: to "better assist victims" $(83 \%)$, "increase victim safety" (83\%), and "improve case management" $(78 \%){ }^{7}$ Faster processing of cases is implied by all three of these reasons: assisting victims in access to justice and more efficient case management necessarily requires that courts provide court users with speedy and just resolutions.

The New York Unified Court System developed Integrated Domestic Violence ("IDV") Courts in 2001.8 In IDV Court, a single judge addresses all of the civil, criminal, and family matters for a single family - including divorce and custody. ${ }^{9}$ IDV Court was designed to respond to the challenges that survivors ${ }^{10}$ of domestic violence experienced in the court systems. ${ }^{11}$ This new court model is the culmination of a series of changes in regulations, protocols, and court procedures for handling domestic disputes. ${ }^{12}$

6 Ctr. for Ct. InNovation, Bridging Theory and Practice: A Roundtable About Court ReSPONSES TO DOMESTIC VIOLENCE, 4 (2006).

${ }^{7}$ Keilitz, supra note 2, at 12.

8 Maytal, supra note 1, at 210. The idea for integrated courts in New York was sparked in part by People v. Wood, a case in which a defendant's criminal charges were considered double jeopardy because they had already been addressed in Family Court. People v. Wood, 742 N.E.2d 114 (N.Y. 2000).

9 Id.

10 The term "victim" has been criticized by domestic violence advocacy organizations as further stigmatizing those who experience it. However, "victim safety" is a term used frequently in literature related to domestic violence courts. I use both terms.

${ }^{11}$ Anita Womack-Weidner, Rural Integrated Domestic Violence Courts: 4th Judicial District Makes It Work, UCS BENCHMARKS 5 (Fall 2005).

12 Eve S. Buzawa \& Carl G. Buzawa, Domestic Violence: The Criminal Justice Response (3d ed. Sage Publications 1993). The feminist movement began to address rape and violence against women, resulting in the emergence of the "battered women's movement." Bernadette Dunn Sewell, History of Abuse: Societal, Judicial, and Legislative Responses to the Problem of Wife Beating, 23 SUFFOLK U. L. REV. 983, 995-97 (1989). See also Maytal, supra note 1, at 202. Police protocols and prosecution have changed primarily as a result of lawsuits. See, e.g., Thurman v. City of Torrington, 595 F. Supp. 1521 (D. Conn. 1984) (holding that a woman's equal protection was violated for inaction in response to her complaints regarding her husband); Estate of Bailey by Oare v. York County, 768 F.2d 503, 510 (3d Cir. 1985) (holding that police have an affirmative duty to protect the personal safety of "women in domestic relationships"). See also Emily Sack, Domestic Violence Across State Lines: The Full Faith and Credit Clause, Congressional Power, and Interstate Enforcement of Protection Orders, 98 Nw. U. L. R. 827, 833 (2004) (referring to the changes in protective orders from two jurisdictions in 1976 to 34 jurisdictions in 1982); Jeffrey Fagan, U.S. Dep't of Justice, Nat'l Inst. of Justice, The Criminalization of Domestic Violence: Promises and Limits 7 (1996), available at 
One would expect this collaboration and concerted effort on improving the justice system for victims of domestic violence would yield faster results than under the traditional system. The data presented here show the contrary: IDV Courts take longer to address motions for civil protective orders, ${ }^{13}$ and are not significantly more likely to grant such orders than traditional matrimonial courts. ${ }^{14}$ In this context, domestic violence survivors spend more time in IDV Court, only to receive the same outcomes as they would under the traditional model. Delays in the civil protective order process suggest that the problem-solving court may not be providing the intended benefits, indicating the need for more thorough analysis before replicating the specialized court model.

\section{IDV Court in Practice}

Domestic violence can trigger a complicated variety of different actions in multiple courts: criminal, civil, and family. One domestic dispute may be result in criminal assault or stalking charges, a motion for divorce, civil protective orders, and child custody and visitation disputes simultaneously. Navigating through the court system is further complicated by the many different organizations aimed at assisting victims, from prosecution offices to community service providers. ${ }^{15}$ While one judge presides over the case, the integration of legal and social services means that there are more professionals involved in IDV Court cases than traditional cases: social workers, batterer intervention programs, criminal and civil attorneys, and well as guardians ad litem or other rep-

http://www.ncjrs.gov/txtfiles/crimdom.txt (citing the first domestic violence civil protective order act in Pennsylvania in 1976).

13 The phrase "protective order" carries many different connotations. I will be using it to refer to a class of orders that individuals take out against one another to protect their personal safety and/or assets. Such orders are also referred to as protection orders, restraining orders, and injunctions. The federal government refers to them as protection orders, defined as "any injunction, restraining order, or any other order issued by a civil or criminal court for the purpose of preventing violent or threatening acts or harassment against, sexual violence, or contact or communication with or physical proximity to, another person, including any temporary or final order issued by a civil or criminal court whether obtained by filing an independent action or as a pendente lite order in another proceeding so long as any civil or criminal order was issued in response to a complaint, petition, or motion filed by or on behalf of a person seeking protection." 18 U.S.C. $§ 2266(5)(A)$. While "protective orders" and "protection orders" are interchangeable terms, I exclusively use "protective order," to avoid confusion with New York's specific Orders of Protection.

${ }^{14}$ See infra pp. 8, 9.

15 Maytal, supra note 1, at 208 (brief description of the coordination concerns between courts and services). 
resentatives for children. ${ }^{16}$ Both within the courts and externally, there is little overlap in technology or communication between groups, potentially causing victims to fall through the cracks. New York's IDV Courts are an attempt to streamline legal processes for families. One judge hears cases that were previously handled in small pieces by multiple judges. ${ }^{17}$

To be eligible for IDV Court, a case must have both a criminal matter and either a civil or family court matter - including divorce, custody, and protective orders. The IDV Court Resource Coordinator screens cases early in the process (e.g., pre-arraignment in criminal cases) to determine whether there are other matters outstanding in other courts. ${ }^{18}$ If so, IDV Court staff members assess whether a case is eligible for removal into IDV Court, and if the (e.g., arraignment) judge agrees, he or she will adjourn the case to be heard in IDV Court. ${ }^{19}$ Eligibility requirements include that the parties be intimate partners (including married couples and dating partners), and that the criminal charge be an allegation of domestic violence, most often an assault charge. ${ }^{20}$ In some courts, attorneys may request that a case be removed to IDV Court based on meeting these eligibility requirements. ${ }^{21}$ Aside from these rare occasions, the process is generally an administrative one, and cannot be appealed by the parties. ${ }^{22}$

Once within IDV Court, all matters before the court retain their distinctions as civil, criminal, or family matters, combining the court rules of all three courts. ${ }^{23}$ These matters "are calendared on the same day but

\footnotetext{
${ }^{16}$ Mazur, supra note 4 , at 9.

17 One Family, One Judge: Integrated Domestic Violence Courts Overview, Office of Policy and Planning, N.Y. State Courts, http://www.courts.state.ny.us/courts/problem_solving/idv/home.shtml.

18 Melissa Labriola et al, A National Portrait of Domestic Violence Courts, Ctr. for Ct. Innovation 42 (Dec. 2009); Domestic Violence Registry: Record Retention and Disposition Schedule, Division of Technology, Family Prot. Registry Ctr. (Aug. 1998),

http://www.courts.state.ny.us/admin/recordsmanagement/OCA/OCA_FamilyProtectionRegistryCenter.p df.

${ }^{19} I d$.

20 Telephone Interviews with Resource Coordinator and staff, Queens County IDV Court, 11th Judicial District, in Kew Gardens, N.Y. (Jan. 26, 2010).

21 Telephone Interview with Clerk, Kings County IDV Court, 2d Judicial District, in Brooklyn, N.Y. (Jan. 26, 2010).

22 Telephone Interview with administrative assistant, Domestic Violence Unit, Suffolk County District Attorney, in Central Islip, N.Y. (Jan. 26, 2010); Telephone Interview with Queens county IDV Resource Coordinator, supra note 20.

${ }^{23}$ See, e.g., Queens IDV Ct. Rules, N.Y. SUP. CT. 11 TH JUD. DiST., available at
} 
scheduled sequentially," allowing the parties to appear once to address several different matters. ${ }^{24}$ Parties file motions with the IDV Clerk, and then await scheduling for hearings.

A civil protection order is one of the remedies available in IDV Court. Protective orders provide a "readily accessible remedy" to victims: instead of waiting for a criminal assault to take place, victims can be proactive about ensuring their own safety by asking for the abuser to be excluded from the home based on other abusive behaviors, such as threats and verbal harassment. ${ }^{25}$ According to the State Justice Institute, "remedies [available under a civil protection order] are often broader than criminal orders issued in conjunction with criminal proceedings and can often prohibit conduct that the police do not view as serious." 26 With a protective order, repeated phone calls or unwanted visits to the home become grounds for arrest.

Either party can file a motion for a civil protective order at any point in divorce proceedings, including at final judgment of a matrimonial action. The judge has broad discretion in deciding whether to grant the order.

\section{Methodology}

Where previous studies have focused on components of criminal domestic violence $\operatorname{cases}^{27}$ such as sentencing, recidivism, and probation, the research reported here is limited to civil protective orders in divorce cases. $^{28}$

http://www.courts.state.ny.us/courts/11jd/supreme/IDV/pubptrules.shtml. Internal rules of IDV Court provide that IDV court judges have authority to hear matters in these respective areas, and that the IDV Court will follow their respective rules of court.

${ }^{24}$ Hon. Judy Harris Kluger and Liberty Aldrich, White Paper, An Argument for a One-Judge/OneFamily Approach to Domestic Violence: Lessons Based on New York's Model, Batterer Intervention Services Coalition of Michigan, Fall Conference, Battle Creek, (Nov. 4, 2009), available at

http://www.biscmi.org/jod/Plenary_3_Integrated_Domestic_Violence_Courts_whitepaper_9.10.09.pdf.

25 Martha Wade Steketee et al., "Implementing an Integrated Domestic Violence Court: Systemic Change in the District of Columbia" 8 (State Just. Inst. June 2000).

$26_{I d}$.

27 See, e.g., Lisa Newmark et al., Specialized Felony Domestic Violence Courts: Lessons on Implementation and Impacts from the Kings County Experience vii, 37 (Urban Inst. Just. Pol'y Ctr., Oct. 2001).

28 I chose divorce cases because they are the clearest indication that the violence is occurring within the family. Civil protective orders outside of divorce may be between intimate partners or other acquaintances. 
Civil protective orders represent a small focus point in a complex universe. Integrated and traditional courts alike deal with "felony domestic violence, misdemeanor domestic violence, civil protection orders, and civil claims." 29 Access to civil orders is a particularly important element of victim safety. The sooner a protective order is granted, the sooner the victim has access to a host of legal remedies, including greater response from law enforcement, and orders from the judge. ${ }^{30}$

This study relies upon active cases, ${ }^{31}$ the dockets of which were extracted from the New York eCourts database, a public database available online. ${ }^{32}$ All cases in the study came before a judge between 2003-2009, from the five boroughs of New York City, as well as Long Island: Kings (Brooklyn), Bronx, New York, Queens, Richmond (Staten Island), Nassau, and Suffolk. ${ }^{33}$ Cases are from both IDV courts and civil matrimonial courts. ${ }^{34}$

When analyzing motions for protective orders, I looked to see how long motions took and what their outcomes were by comparing the following information: 1) the duration of the motion, or how many days lapsed between the date the motion was filed and the date the motion was heard, ${ }^{35}$ and 2) whether the motion was granted. ${ }^{36}$ Two distinct forms of protective orders are included in this study: Orders of Protection and Orders for Exclusive Occupancy of the Residence.

${ }^{29}$ Susan Keilitz et al., Tracking and Understanding Family Violence Caseloads, 5 Caseload Highlights 1,1 (Nat'l Ctr. for St. Cts. Apr. 1999).

${ }^{30}$ See Orders of Protection, infra.

31 Only active cases are available on the database. Cold cases are not online.

32 New York eCourts Database, http://www.courts.state.ny.us/ecourts/.

33 There are far more cases in matrimonial courts than IDV courts. Within the selected counties, I included every IDV court case from 2003-2009 with a motion for an Order of Protection or for Exclusive Occupancy of the Residence - twelve IDV judges. With over forty matrimonial courts in those jurisdictions, I selected nine matrimonial judges at random. See Appendix A, infra p. 16.

${ }^{34}$ Divorces are not heard in family court, but some civil judges specialize in a matrimonial docket. To generate comparable cases, searches were limited to divorce cases, or "matrimonial: contested" cases as listed in the New York eCourts database.

${ }^{35}$ Generally motions have a filing date and a hearing date listed. If a motion had a filing date listed but no hearing date, I considered it to be an open case. If the motion had been pending for over a year, I input the duration to be 365 days.

36 Different court clerks use different terminology when entering data into the eCourts database. A motion was considered granted (or a positive outcome) if it was listed as "granted," "ordered," "rendered," "settled," or if they made a reference to the details of the order (e.g., "see memo"). Motions were considered not granted if they were listed as "withdrawn," "declined," "moot," "denied," "adjourned," or "dismissed." If a motion was not heard for over a year after the filing date, it was considered not granted. 
Orders of Protection ${ }^{37}$ ("OPs"), or more commonly, "restraining orders," 38 can be temporary ${ }^{39}$ or permanent, and can require an individual to: stay away from particular people or places (e.g., children's school, partner's place of business); refrain from communicating with particular people; refrain from already criminal acts (e.g., stalking, sexual abuse, intimidation); injuring pets; or even refrain from specific acts "that create an unreasonable risk to the health, safety, or welfare" of specific family members (e.g., drinking alcohol). ${ }^{40}$ OPs can also require individuals to pay restitution or counsel fees, or participate in "batterer's education programs." 41 In order to obtain an OP, a party must successfully plead a "family offense" according to article 8 of the Family Court Act. ${ }^{42}$ Temporary orders can be granted immediately and ex parte, but permanent orders require a hearing.

Exclusive Occupancy Orders ${ }^{43}$ ("EOs") are a common component of ordinary divorce cases, where the parties have determined that one shall keep the marital property and the other presumably receives some other marital assets. ${ }^{44}$ Pendente lite ("pending the litigation") orders, however, can also be granted in cases where it is necessary to protect one spouse's safety during the course of the divorce proceedings. ${ }^{45}$ I only included pendente lite EOs in this study.

Cases in IDV courts and civil matrimonial courts do not share the general profile. Civil matrimonial courts include all contested divorce cases along a spectrum from mild disagreement over alimony to cases with some intimidation or physical violence between parties. IDV cases tend to be more severe: cases enter IDV Court only if there have been

${ }^{37}$ N.Y. DOM. REL. L. $\$ \$ 240,252$.

38 See discussion of terms for protective orders, supra note 13.

${ }^{39}$ N. Y. COMP. CODES R. \& REGS. tit. 22, § 202.7 (1986, am. 2007) for stays and temporary restraining orders. This study only includes permanent Orders of Protection.

${ }^{40}$ Form SC-1, Temporary Order of Protection, Supreme Court of New York, 9/2009; Form SC-2, Order of Protection, Supreme Court of New York, 9/2009.

${ }^{41}$ Form SC-2, Order of Protection, supra note 40.

${ }^{42}$ N.Y. FAM. Cт. АСт §812(1). See, e.g., Kristiansen v. Kristiansen, 144 A.D.2d 441 (2d Dep't 1988); Fakiris v. Fakiris, 177 A.D.2d 540, 544 (2d Dep't 1991). Parties must plead a family offense whether the OP is filed in Family Court or civil court.

${ }^{43}$ N.Y. DOM. REL. L. $\$ 234,236$ B(5)(f).

44 The standard for obtaining an EO is broader than that for an OP: any set of facts that would indicate that "such relief is necessary to protect the safety of persons or property." EOs meet the definition of a protection order outlined in Violence Against Women Act, 18 U.S.C. $\$ 2266(5)(A)$, supra note 13.

45 See, e.g., Scampoli v. Scampoli, 37 A.D.2d 614 (2nd Dept. 1971); King v. King, 109 A.D.2d 779, 486 N.Y.S.2d 291 (2d Dep’t 1985); Mayeri v. Mayeri, 208 N.Y.S.2d 44 (N.Y. Sup. 1960). 
criminal assault charges, meaning that physical violence is alleged in all of the cases.

\section{Finding 1: IDV Court Takes Longer}

One of the goals of IDV court is to create a streamlined, more efficient process, thanks to the model of "one family, one judge." 46 Rather than shifting from courtroom to courtroom to handle various issues in a case, families meet before the same judge for their civil, criminal, and family matters. A more streamlined process is intended to provide faster outcomes to families, on everything from the ultimate disposition of the case to hearings on Orders for Protection and Exclusive Occupancy. ${ }^{47}$

The goal of IDV Court is to promote "quick judicial action" to address the time-sensitive nature of the case, according to the Center for Court Innovation. ${ }^{48}$ It offers judicial monitoring, coordination between the court and outside services, and a judge and staff dedicated to and trained on domestic violence issues. ${ }^{49}$ IDV Court eliminates the need for families to appear in multiple courts for the various pieces of the same dispute. ${ }^{50}$ IDV Court judges assert that the one-family, one-judge model increases efficiency. ${ }^{51}$ The New York-based Center for Court Innovation, which promotes the development of new IDV courts throughout New York State, claims that specialized domestic violence courts increase victim safety and efficiency, "streamlin[ing] the process for all participants." 52

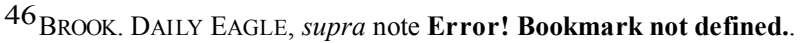

${ }^{47}$ Mazur, supra note 4, at 4.

48 Robert V. Wolf et al., Planning a Domestic Violence Court: The New York State Experience, Ctr. for Ct. Innovation 5-6 (2004).

${ }^{49}$ Domestic Violence Courts Overview, Office of Policy and Planning, N.Y. State Courts, http://www.courts.state.ny.us/courts/problem_solving/dv/home.shtml.

50 One Family, One Judge, supra note 17.

51 Samuel Newhouse, “One Family, One Judge,” at Brooklyn's Integrated Domestic Violence Courts, BRoOK. Daily EAgle (Apr. 8, 2009) (quoting IDV Court justices Morgenstern and Henry). I am interpreting "efficiency" in this context to mean the absence of delay.

${ }^{52} \mathrm{Ctr}$. for Ct. Innovation, Integrated Domestic Violence Courts: What Are They?,

http://www.courtinnovation.org/index.cfm?fuseaction=Page. ViewPage\&PageID=604\&currentTopTier $2=$ true.
} 


\section{FIGURE 1: DAYS ELAPSED FROM MOTIONS FOR PROTECTIVE ORDERS TO DECISION, BY COURT}

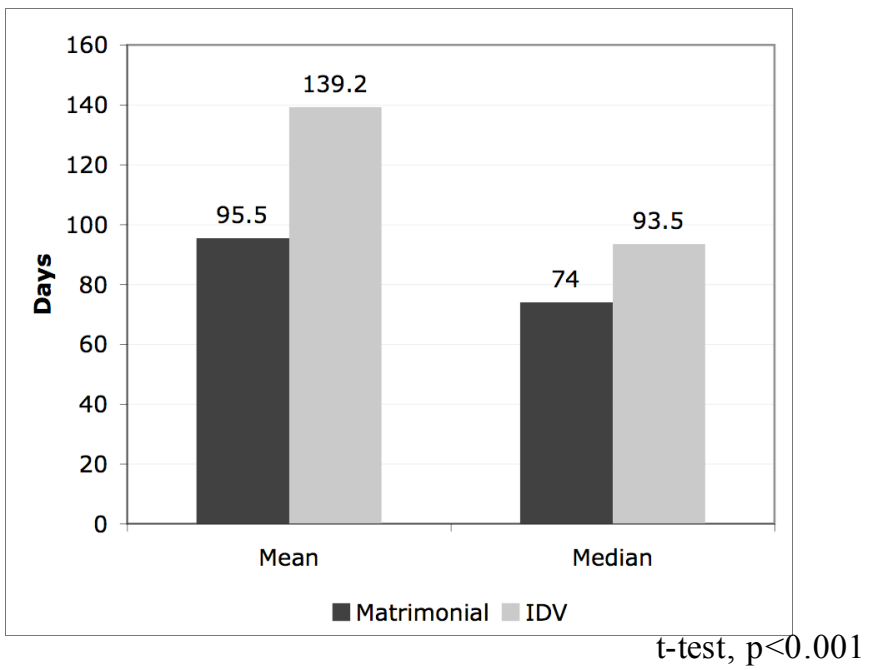

Speed was not the result. Of the 421 observed cases, the average duration of a protective order motion was longer in IDV court than in traditional civil matrimonial court from the date it was filed to the date it was heard before a judge. ${ }^{53}$ The mean duration in IDV Court was over a month longer than the mean duration in matrimonial court. The median in IDV Court was twenty days longer.

\section{Finding 2: Outcomes are the Same}

While the standard is the same for all judges issuing protective orders, the IDV Court makeup is a different subset of cases. Cases that come before the IDV Court tend to be more severe, and come with greater attention to the safety concerns for both parties. Because of the increased severity of IDV cases and the policy focus in IDV Court on victim safety, the IDV Court seems more likely to yield a higher number of motions granted than the traditional matrimonial court. Given the criminal matters associated with IDV cases, these motions tend to reflect higher risk than traditional divorces, warranting greater attention to victim safety.

${ }^{53}$ T-test, $\mathrm{p}<0.01$. 
This was not the case. Of the 454 remaining motions with a clear outcome, nearly as many motions for protective orders were granted in traditional courts. ${ }^{54}$

TABLE 1: MOTIONS FOR PROTECTIVE ORDER GRANTED, BY COURT

\begin{tabular}{|c|c|c|c|}
\hline Court & Granted & Total & \% Granted \\
\hline Matrimonial & 162 & 366 & $44 \%$ \\
\hline IDV & 42 & 88 & $48 \%$ \\
\hline \multicolumn{3}{|c}{ Pearson $\chi$-square, $\mathrm{p}=0.557$} \\
\hline
\end{tabular}

The difference between matrimonial and IDV courts was not statistically significant. A party seeking a protective order had the same chance of a positive result in either court.

Each IDV Court in the state was initiated individually, through its own grant application process to the federal Office of Violence Against Women (OVW) and facilitated by the statewide Unified Court System. ${ }^{55}$ As a result, the primary focus has historically been on violence against women. When breaking down the protective order motions by gender, however, there was no significant difference in percentage of motions granted to wives against their husbands. ${ }^{56}$

TABLE 2: WIFE-INITIATED MOTIONS FOR PROTECTIVE ORDER GRANTED, BY COURT

\begin{tabular}{|c|c|c|c|}
\hline Court & Granted & Total & \% Granted \\
\hline Matrimonial & 117 & 258 & $55 \%$ \\
\hline IDV & 30 & 58 & $48 \%$ \\
\hline \multicolumn{3}{|r}{ Pearson $\chi$-square, $\mathrm{p}=0.379$} \\
\hline
\end{tabular}

\footnotetext{
${ }^{54}$ In 98 of the observed cases, there was no discernible outcome on the motion for a protective order. The clerks of two IDV court judges, Judges Ayres and Crecca, used the term "motion decided" to indicate the disposition for most motions. Given that "decided" does not clearly indicate whether it was decided favorably or not, all cases with the disposition "decided" were only considered for their data on motion duration.

55 Telephone Interview with Pamela Kravetz, Grants/Contracts Manager, Division of Grants and Program Development, New York State Unified Courts System, in New York, N.Y. (Dec. 14, 2009).

56 New York does not grant same-sex marriages, but does recognize out-of-state same-sex marriages. No same-sex dissolutions were observed in this study.
} 
These data suggest that, contrary to all the intentions of those who constructed these courts, high-risk cases are not receiving a higher level of scrutiny or focus on victim safety.

\section{Variation by Judge $\mathbf{5 7}^{57}$}

Although motions do not vary significantly by court, there is a high degree of variation by judge. Judges in the study granted anywhere from 8 to $100 \%$ of protective order motions in IDV Court, and anywhere from 15 to $53 \%$ in matrimonial court. ${ }^{58}$

\section{FIGURE 2: MOTIONS FOR PROTECTIVE ORDER GRANTED, BY JUDGE}

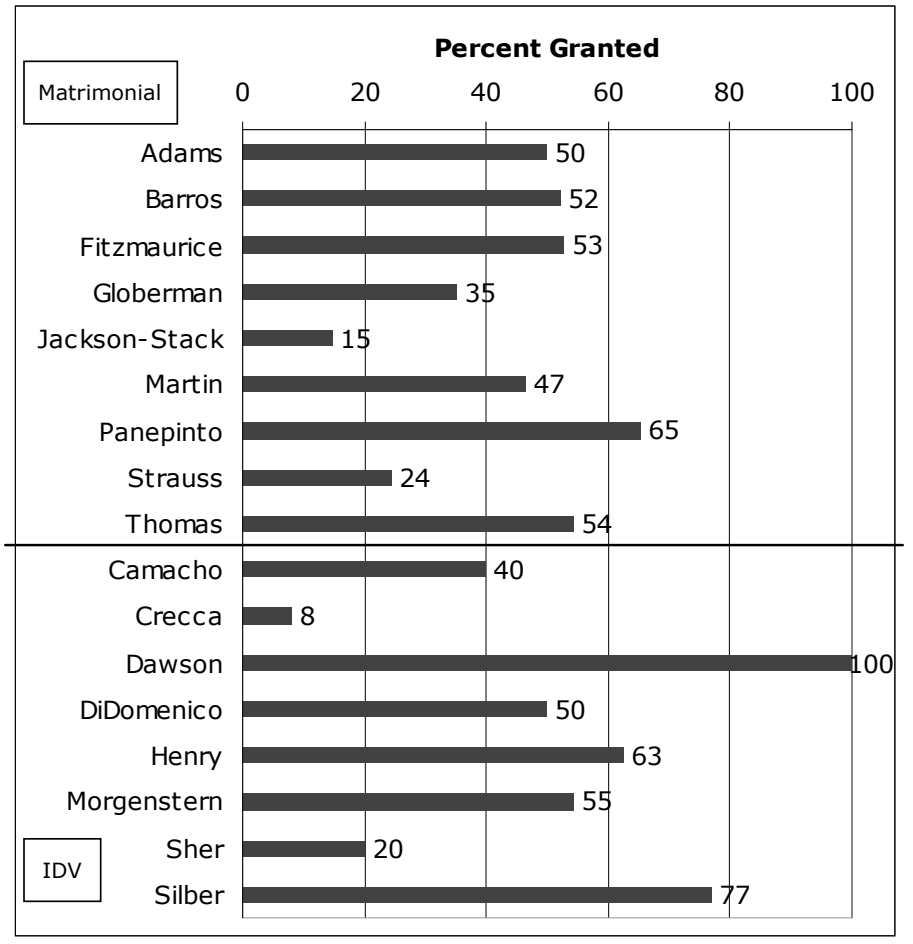

Pearson $\chi$-square, $\mathrm{p}<0.001^{59}$

57 See Appendix B, infra p. 17.

58 Some of the IDV courts in the study had very small sample sizes, making the data seem more extreme, but judges with fewer than 5 cases with outcomes were removed: Farneti $=3$, Harrington $=3$, Kiesel $=1$.

${ }^{59}$ For more specific information on the number of cases before each judge, see Appendix B, infra $\mathrm{p}$. 17. 
Differences remain in the way that domestic violence is treated in the courts. However, these differences are between matrimonial and IDV courts, but rather, between and among judges. ${ }^{60}$ In any one case, regardless of its own merits, a party seeking a restraining order has a greater likelihood of receiving one in Judge Silber's court than in Judge JacksonStack's court, for example.

Some systematic variation is expected in any courtroom setting. ${ }^{61}$ Judges tend to approach the bench with consistent styles, and base opinions on their own well-formed ideas of unique cases. However, IDV Court aims to promote greater consistency across courts, which would limit variation between judges. In the words of the IDV Court's Administrative Judge, "IDV Courts aim to provide more informed judicial decisionmaking and greater consistency in court orders."62 In fact, variation among judges is, if anything, greater in IDV Courts than matrimonial courts. ${ }^{63}$

\section{Discussion}

\section{Explanations for the Data}

Why do IDV courts take longer in assessing protective order motions? Surely it is not because court staff and judges recognize the importance of these motions any less than their Supreme Court counterparts. According to anecdotal evidence, it seems that temporary orders are equally accessible across courts - it is the formal decision of a permanent order where the disparity is most clear. ${ }^{64}$

One possibility is that in the holistic IDV model, judges prioritize matters within a case differently, e.g., addressing criminal charges first,

\footnotetext{
60 Pearson $\chi$-square, $\mathrm{p}<0.001$.

61 See, e.g., Chris Guthrie, The 'Hidden Judiciary': An Empirical Analysis of Executive Branch Justice, 58 DUKE L.J. 1477, 1500 et seq. (2009) (describing anchoring bias and other bias in decisionmaking for judges, Administrative Law Judges, and college students).

62 Id. See also Mandy Burton, Judicial Monitoring of Compliance: Introducing 'Problem-Solving' Approaches to Domestic Violence Courts in England and Wales, 20 INT'L J.L. POL'Y \& FAM. 366, 368 (2006) (discussing the benefit of preventing inconsistent orders). Conflicting court orders or redundant court orders has come up time and again. See, e.g., Carolyn D. Schwarz, United Family Courts: A Saving Grace for Victims of Domestic Violence Living in Nations With Fragmented Court Systems, 42 FAM. CT. REV. 304, 311-12 (Apr. 2004).

63 This is consistent with observations of an integrated court in Washington, D.C. See Steketee, supra note 25 , at 67 .

64 Interview with Erie County Family Court Judge, in Cambridge, Mass. (Mar. 29, 2010).
} 
then the custody of the children, before ruling on protective orders. Addressing three different matters within one court appearance poses a significant administrative burden on the individual Court.

Compounding that burden is the large number of advocates, legal and non-legal, that must come together at the same time for a given appearance. It may be simply more difficult for all the necessary participants to schedule an appearance at all in IDV court, meaning that parties must wait longer before addressing their motions.

IDV courts that take longer than traditional courts in processing civil protective orders do not meet the goals of efficiency or victim safety. ${ }^{65}$ As stated by the Center for Court Innovation, " $[t]$ he longer the victim must wait for legal action, the longer she is at risk." 66

\section{Re-thinking IDV Court}

The delays in the civil protection order process do not necessarily imply that the specialized court model should be abandoned. Rather, these results indicate the need for a closer eye on the results of court innovations, and a firmer foundation for why such innovations are implemented. For example, while IDV Court proponents claim that having one judge creates efficiency, efficiency is clearly not the reason there are social services staff present at hearings - insofar as efficiency means speedy acquisition of necessary protective orders (and speedy denial of unnecessary motions). Other goals of the Court include victim satisfaction with the process as well as increased defendant accountability. ${ }^{67} \mathrm{Al}-$ though advocates in the courtroom may have the potential to slow down hearings, they may be working with both parties to ensure satisfaction and accountability beyond the courtroom. ${ }^{68}$ Increased attention to both parties in the case by legal and social services may also be reducing recidivism, which achieves the goal of victim safety on a much broader level. ${ }^{69}$

\footnotetext{
65 Keilitz, supra note 2; Mazur, supra note 4, at 4.

66 Mazur, supra note 4 , at 4.

${ }^{67}$ Burton, supra note 62, at 368-369.

68 CTR. FOR CT. INNOVATION ROUNDTABLE, supra note 6, at 4 (citing several studies from 1999-2002, referring to criminal DV courts only). Victim satisfaction does not necessarily correlate to improved outcomes, as "the court experience itself is only a small percentage of the complainant's total experience with the case."

${ }^{69}$ E.g., Adele Harrell et al., The Evaluation of Milwaukee's Judicial Oversight Demonstration, Urban Institute Just. Pol'y Ctr. 11 (Apr. 2006).; Elena Salzman, The Quincy District Court Domestic Violence Prevention Program: A Model Legal Framework for Domestic Violence Intervention, 74 B.U. L. REV. 329, 344 n.83 (1994). Suprisingly, reducing recidivism was not listed as a top priority for the Court.
} 
While these are all possible benefits to the IDV model, policy-makers in New York have yet to determine whether IDV Court is successfully achieving these results in those arenas. Although there have been evaluations of victim satisfaction in domestic violence courts generally, the New York IDV Court has not engaged in any such analysis, nor has there been review of recidivism or other factors. ${ }^{70}$ Individual performance review is necessary to determine what is actually working for this court, as other specialized courts throughout the country have yielded mixed results. ${ }^{71}$

The available data suggest that the IDV Court model does not improve efficiency and victim safety in the realm of civil protective orders.

\section{Conclusion}

Policy-makers see the rapid expansion of specialized courts as proof that the model is a successful one. ${ }^{72}$ IDV Courts are replicating without assessment of the impact they are having on families. ${ }^{73}$ While the impact of victim advocates and defendant accountability measures is unknown, the available measurement of the Court indicates that the Court is not fully achieving its mission of a faster and more consistent system.

Civil protective orders take longer to process in IDV Court, but are not more likely to be granted. Civil protective orders form one small piece of domestic violence cases, but a crucial one. Protective orders are designed to increase victim safety, and they require efficiency in case process in order to function properly. So long as the goals of the Court include victim safety and efficiency, they demand prompt and consistent resolution of protective orders. The current procedure of long waits for

Keilitz, supra note 2, at 12 . Increasing victim safety and reducing recidivism may be correlated, but the specific goal of reducing recidivism was not widely discussed by survey participants.

$70_{\text {Keilitz, supra note } 2 \text {, at } 9 .}$.

71 Milwaukee, Wisconsin's criminal domestic violence court and the Quincy, Massachusetts integrated civil-criminal domestic violence court both reviewed their overall performance. Victim satisfaction with the court did not increase in Quincy, and decreased in Milwaukee, compared to nonspecialized courts. Robert C. Davis et al., Increasing Convictions in Domestic Violence Cases: A Field Test in Milwaukee, 22 JusT. SYS. J. 61, 68 (2001); Eve Buzawa et al, Response to Domestic Violence in a Pro-Active Court Setting, Nat'l Crim. Just. Reference Svcs. 15 (Mar. 1999).

72 Chief Judge Judith S. Kaye, State of the Judiciary Address (Jan. 2001), in State of the Judiciary Address, New York, N.Y (2001), at 6.

73 IDV Courts have expanded from two in 2001 to twenty-eight in 2005 to forty-four in 2009.

Womack-Weidner, supra note Error! Bookmark not defined., at 5; One Family, One Judge, supra note 17 . 
orders, combined with judge-specific differences in case outcomes, is inadequate to its mission. Good intentions alone are insufficient to design an effective court system. As this study indicates, court design and implementation demands more concrete goals, with thorough review to ensure that those goals are being achieved. For example, it is unclear whether other elements of the program are more successful. Do victims of domestic violence who access the court report higher degrees of satisfaction with their experience than those in traditional matrimonial court? Do families who use the social services provided by IDV Court have lower rates of recidivism than under the traditional legal system? These questions warrant careful consideration before the integrated court model expands. 
16

APPENDIX A: CASES, BY JUDGE

\begin{tabular}{|l|r|r|}
\hline \multicolumn{1}{|c|}{ Judge } & Frequency & \multicolumn{1}{c|}{ Percent } \\
\hline Adams (Kings) & 64 & 12 \\
\hline Barros (Kings) & 23 & 4 \\
\hline Fitzmaurice (Queens) & 53 & 10 \\
\hline Globerman (Bronx) & 37 & 7 \\
\hline Jackson-Stack (Nassau) & 82 & 15 \\
\hline Martin (Bronx) & 15 & 3 \\
\hline Panepinto (Richmond) & 52 & 10 \\
\hline Strauss (Queens) & 41 & 8 \\
\hline Thomas (Kings) & 35 & 6 \\
\hline Matrimonial & $\mathbf{4 0 2}$ & $\mathbf{7 4}$ \\
\hline
\end{tabular}

\begin{tabular}{|c|c|c|}
\hline Ayres (Nassau) & 6 & 1 \\
\hline Camacho (Queens) & 5 & 1 \\
\hline Crecca (Suffolk) & 41 & 8 \\
\hline Dawson (NY) & 5 & 1 \\
\hline DiDomenico (Richmond) & 10 & 2 \\
\hline Farneti (Suffolk) & 20 & 4 \\
\hline Harrington (Queens) & 3 & 1 \\
\hline Henry (Kings) & 8 & 1 \\
\hline Kiesel (Bronx) & 1 & 0.2 \\
\hline Morgenstern (Kings) & 22 & 4 \\
\hline Sher (Nassau) & 9 & 2 \\
\hline Silber (Richmond) & 13 & 2 \\
\hline IDV & 143 & 26 \\
\hline Total & 545 & 100 \\
\hline
\end{tabular}


APPENDIX B: MOTIONS GRANTED, BY JUDGE

\begin{tabular}{|c|c|c|c|}
\hline Judge & Granted & Total & $\%$ Granted \\
\hline
\end{tabular}

Matrimonial

\begin{tabular}{|l|c|c|c|}
\hline Adams (Kings) & 32 & 64 & 50 \\
\hline Barros (Kings) & 12 & 23 & 52 \\
\hline Fitzmaurice (Queens) & 28 & 53 & 53 \\
\hline Globerman (Bronx) & 13 & 37 & 35 \\
\hline Jackson-Stack (Nassau) & 7 & 47 & 15 \\
\hline Martin (Bronx) & 7 & 15 & 47 \\
\hline Panepinto (Richmond) & 34 & 52 & 65 \\
\hline Strauss (Queens) & 10 & 41 & 24 \\
\hline Thomas (Kings) & 19 & 35 & 54 \\
\hline
\end{tabular}

IDV

\begin{tabular}{l}
\begin{tabular}{|l|c|c|c|}
\hline Camacho (Queens) & 2 & 5 & 40 \\
\hline Crecca (Suffolk) & 1 & 12 & 8 \\
\hline Dawson (NY) & 5 & 5 & 100 \\
\hline DiDomenico (Richmond) & 5 & 10 & 50 \\
\hline Henry (Kings) & 5 & 8 & 63 \\
\hline Morgenstern (Kings) & 12 & 22 & 55 \\
\hline Sher (Nassau) & 1 & 5 & 20 \\
\hline Silber (Richmond) & 10 & 13 & 77 \\
\hline
\end{tabular} \\
Total \\
\hline
\end{tabular}

${ }^{+}$In 98 of the 545 cases in this study, the outcomes of civil protective order motions were unclear. See explanation, supra note 54 . 